\title{
Enhancing college students' critical thinking skills in cooperative groups
}

\author{
Helena Silva \\ Escola de Ciências Humanas e Sociais \\ Departamento de Educação \\ Universidade de Trás-os-Montes e Alto \\ Douro \\ Vila Real, Portugal \\ CIIE - Centro de Investigação e \\ Intervenção Educativas \\ Faculdade de Psicologia e Ciências da \\ Educação \\ Universidade do Porto \\ Porto, Portugal \\ helsilva@utad.pt
}

\author{
José Lopes \\ Escola de Ciências Humanas e Sociais \\ Departamento de Educação \\ Universidade de Trás-os-Montes e Alto \\ Douro \\ Vila Real, Portugal \\ CIIE - Centro de Investigação e \\ Intervenção Educativas \\ Faculdade de Psicologia e Ciências da \\ Educação \\ Universidade do Porto \\ Porto, Portugal \\ jlopes@utad.pt
}

\author{
Caroline Dominguez \\ Escola de Ciência e Tecnologia \\ Departamento de Engenharias \\ Universidade de Trás-os-Montes e Alto \\ Douro \\ Vila Real, Portugal \\ LabDCT/CITDFF - Laboratório de \\ Didática de Ciências e Tecnologial \\ Centro de Investigação Didática e \\ Tecnologia na Formação de Formadores \\ Universidade de Aveiro \\ Aveiro, Portugal \\ carold@utad.pt
}

\begin{abstract}
This study examines the effects of cooperative learning interventions on college students' critical thinking (CT) development. It presents the results of an investigation in which 19 students were assigned to work in a cooperative learning (experimental group) context, and 22 other students (control group) followed a lecturebased learning process. The development of the students' critical thinking skills was subsequently assessed with a pre- and post-test. The results showed greater improvements in critical thinking skills among the students of the intervention group suggesting clearly that the effects of cooperative learning are very positive.
\end{abstract}

\section{Keywords-critical thinking, cooperative learning, lecture- based learning}

\section{INTRODUCTION}

Educators, professors, and researchers alike believe that the development of critical thinking skills is essential for students because of their academic and real-world applications [1] [2]. Critical thinking generally leads to well-informed, more reasoned decision making processes [3] and is considered vital to the success of a democratic society [4]. Without critical thinking, society members are less equipped to engage in public discourse and participate in active citizenship. Critical thinking, a component of higher-order thinking [5] is a highly required educational skill that combines argument analysis problem solving and decision-making [6] [7] [8] [9] [10] [11]. It is generally described as an individual's ability to evaluate and analyze arguments to determine which ones have merit and which not [7] [12]. It includes the capacity for interpretation, analysis, evaluation, inference, explanation and self-regulation [13]. Despite critical thinking importance, if significant percentages of college students successfully complete requirements for graduation, they do not progress, as expected, in the development of their critical thinking skills [14] [15]. In that sense, it is necessary to examine how these skills can be promoted in the classroom [16] along their academic path.

One of strategies that has been pointed out as being effective to develop critical thinking is cooperative learning [17] [18] [19] [20] [2]. Cooperative learning refers to students working together in an attempt to create knowledge and achieve shared learning goals [21] [22]. Previous work [23] [24] [25], offered a persuasive argument on why cooperative learning might positively influence students' cognitive development. First, it is believed that cognitive disequilibrium occurs as a result of the sociocognitive conflict that arises when individuals work together to achieve shared educational goals. Next, it is thought that the construction of new knowledge is often built on students' experiences when working with others in the cooperative learning process. As some authors argued [25], "cooperative learners cognitively rehearse and restructure information to retain it in memory and incorporate it into existing cognitive structures" (p. 120). This process is thought to occur when members of the group are exposed to the intellectual diversity of others in the group as they are confronted with innovative or different ways of looking at familiar problems [26]. Viewed from Piaget's perspective, instructors can be seen as facilitators of students' learning, rather than people who simply deliver content to students. This orientation allows for social interaction, cognitive conflicts, and therefore disequilibrium in students, which in turn spurs intellectual development and cognitive growth [27].

In short, cooperative learning approaches may lead to the development of the need for cognition, by helping students enjoy the process of learning together and may be more efficient to develop critical thinking than through a lecture or individual educational approaches [28] [29] [30]. Although most of the research on outcomes associated with cooperative learning has been conducted at the primary and secondary 
levels of education [31], there is an emerging literature on this issue at the higher education level as well [32] [33] [34]. In higher education, cooperative learning has been identified as a promising and effective instructional approach [35]. However, there is little evidence drawn from experimental research supporting that cooperative learning influences positively college students' cognitive development in general and criticalthinking skills in particular [36] [37] [38].

This gap in the literature is rather surprising given that critical thinking is cited by employers and college professors alike as one of the most important learning outcomes among college students [39] [40]. This paper addresses this gap and contributes to demonstrate how using cooperative learning strategies may assist students in developing critical thinking skills. To the best of our knowledge few research studies have focused on the link between the pedagogic cooperative approach and the enhancement of college students' critical thinking skills. The present study was therefore carried out to contribute to this reflection and address the following research question: is there any statistically significant difference between the development of college students' critical thinking skills using a cooperative learning approach or using a traditional lecture-based approach?

\section{METHOD}

\section{A. Design}

To answer to the question above, a nonequivalent control group pretest-posttest design was used in this quasiexperimental study. The research compared the effects of instruction on critical thinking skills using cooperative learning strategies versus traditional lecture-based classes[41].

\section{B. Participants}

The participants were 41 students from two classes of a public university from the North of Portugal divided in two groups of the 3rd year college, one undergraduate course in Psychology (control group with 22 students) and the other in Basic Education (experimental group with 19 students). Regarding gender, $87.8 \%$ were females and ages ranged between 19 and $37(\mathrm{M}=20.8 ; \mathrm{SD}=3.18)$.

\section{Measures}

The measure used to evaluate the development of critical thinking came up from the application and results of a Critical Thinking Test (CTT) elaborated by the authors and already validated for the Portuguese higher education population [42]. The CTT presents a common problem situation of daily life, in which problematic circumstances can be identified. The respondent is asked to answer a set of six questions, which refer to different cognitive tasks which require for their appreciation and resolution, the use of a critical thinking skill, taking in consideration the Bloom's taxonomy reviewed by the reference [43] and [13] critical thinking skills classification: (i) interpretation, (ii) analysis, (iii) explanation, (iv) evaluation, (v) synthesis and (vi) production/creation.

In question 1 the respondent is asked to identify the problem contained in the described situation in order to assess his / her capacity to interpret - understand and express the meaning of a wide variety of experiences, situations, data, events, judgments, conventions, beliefs, rules, procedures or criteria. In question number 2 , the respondent is asked to identify and then compare solutions to solve the problem, to evaluate his / her analytical capacity - to present the main ideas and to relate them to each other, involving the decomposition of the material into its constituents' parts, and determine how the parties relate to each other and to the general structure of information. In question 3 the respondent is asked to select the best solution and to present an argument in its defense, in order to evaluate his/her capacity for explanation - to present the result of his own reasoning and to justify this reasoning with valid arguments. In question 4 the respondent is asked to evaluate the quality of the defended solution in order to evaluate his / her capacity for evaluation - to evaluate the credibility of arguments, representations, descriptions of perceptions, experiences, situations, evaluations, beliefs or personal opinions, as well as the inferential relationships between arguments, descriptions, questions or other forms of representation. Finally, in question number 5, the respondent is asked to propose strategies to maximize the quality of the solution he or she advocates, to evaluate his/her capacity for synthesis - to create a new idea from other ideas and to build knowledge based on the collection and information processing. Each of the five questions are answered openly by respondents on a response sheet.

After the test, the responses were scored from an evaluation rubric. For each of the five questions relating to a critical thinking skill under evaluation, the evaluator scored the student's response on a four-point scale: (3 points), ( 2 points), (1 point) and ( 0 points). These points were attributed, according to the critical thinking skill evaluated by each question, in logic of quality and quantity (Table 1).

\section{TABLE I. SCORING RUBRIC TO EACH DIMENSION OF CRITICAL THINKING} EVALUATED

\begin{tabular}{|c|c|c|}
\hline Dimension & Criteria & Score \\
\hline \multirow{4}{*}{ 1. Interpretation } & $\begin{array}{l}\text { The answer is complete, well-founded and } \\
\text { organized. }\end{array}$ & 3 \\
\hline & $\begin{array}{l}\text { The answer is incomplete, poorly grounded } \\
\text { and poorly organized. }\end{array}$ & 2 \\
\hline & $\begin{array}{l}\text { The answer is incomplete, unsubstantiated } \\
\text { and confused. }\end{array}$ & 1 \\
\hline & The answer is entirely incorrect. & 0 \\
\hline \multirow{4}{*}{ 2. Analysis } & $\begin{array}{l}\text { The answer identifies all the possible } \\
\text { solutions, or at least two differences and a } \\
\text { similarity between the solutions. }\end{array}$ & 3 \\
\hline & $\begin{array}{l}\text { The answer identifies two possible } \\
\text { solutions, or two differences, or a } \\
\text { difference and a similarity between the } \\
\text { solutions. }\end{array}$ & 2 \\
\hline & $\begin{array}{l}\text { The answer identifies only one possible } \\
\text { solution, or a difference or a similarity } \\
\text { between the solutions. }\end{array}$ & 1 \\
\hline & $\begin{array}{l}\text { The answer doesn't identify any solution, } \\
\text { or doesn't establish any comparison } \\
\text { between the solutions. }\end{array}$ & 0 \\
\hline \multirow[t]{2}{*}{ 3. Explanation } & $\begin{array}{l}\text { The argument contained in the answer is } \\
\text { coherent and has two or more justificatory } \\
\text { premises. }\end{array}$ & 3 \\
\hline & $\begin{array}{l}\text { The argument contained in the answer is } \\
\text { coherent and has a justification. }\end{array}$ & 2 \\
\hline
\end{tabular}




\begin{tabular}{|c|c|c|c|}
\hline & \multicolumn{2}{|c|}{$\begin{array}{l}\text { The argument contained in the answer is } \\
\text { inconsistent. }\end{array}$} & 1 \\
\hline & \multicolumn{2}{|c|}{$\begin{array}{l}\text { The argument contained in the answer is } \\
\text { invalid. }\end{array}$} & 0 \\
\hline \multirow{4}{*}{ 4. Evaluation } & \multicolumn{2}{|c|}{$\begin{array}{l}\text { The answer is consistent and presents at } \\
\text { least three weaknesses. }\end{array}$} & 3 \\
\hline & \multicolumn{2}{|c|}{$\begin{array}{l}\text { The answer is consistent and/or presents } \\
\text { two weaknesses. }\end{array}$} & 2 \\
\hline & \multicolumn{2}{|c|}{$\begin{array}{l}\text { The answer is inconsistent and/or presents } \\
\text { one weakness. }\end{array}$} & 1 \\
\hline & \multicolumn{2}{|c|}{$\begin{array}{l}\text { The answer presents invalid and/or doesn't } \\
\text { present weaknesses. }\end{array}$} & 0 \\
\hline \multirow{4}{*}{ 5. Synthesis } & \multicolumn{2}{|c|}{$\begin{array}{l}\text { The argument contained in the answer } \\
\text { consistently improve all the weaknesses of } \\
\text { a solution or create a new solution. }\end{array}$} & 3 \\
\hline & \multicolumn{2}{|c|}{$\begin{array}{l}\text { The argument contained in the answer is } \\
\text { presented in a coherent way and improves } \\
\text { some of the weaknesses of a solution. }\end{array}$} & 2 \\
\hline & \multicolumn{2}{|c|}{$\begin{array}{l}\text { The argument contained in the answer is } \\
\text { inconsistent with the weaknesses of the } \\
\text { related solution. }\end{array}$} & 1 \\
\hline & \multicolumn{2}{|c|}{$\begin{array}{l}\text { The argument contained in the answer } \\
\text { doesn't improve the identified weaknesses. }\end{array}$} & 0 \\
\hline \multirow{11}{*}{ 6. Production/creation } & \multirow{4}{*}{ Fluency } & $\begin{array}{l}\begin{array}{l}\text { Presents more than two } \\
\text { solutions. }\end{array} \\
\end{array}$ & 3 \\
\hline & & Presents two solutions. & 2 \\
\hline & & Presents one solution. & 1 \\
\hline & & Doesn't answer. & 0 \\
\hline & \multirow{3}{*}{ Flexibility } & $\begin{array}{l}\text { The solution presented serve } \\
\text { to solve the problem. }\end{array}$ & 2 \\
\hline & & $\begin{array}{l}\text { The solution presented } \\
\text { serves to solve the problem } \\
\text { or some of the solutions } \\
\text { serve to solve the problem. }\end{array}$ & 1 \\
\hline & & $\begin{array}{l}\text { None of the solutions serve } \\
\text { to solve the problem or are } \\
\text { equal to the ones proposed in } \\
\text { the text. }\end{array}$ & 0 \\
\hline & \multirow{4}{*}{ Originality } & $\begin{array}{l}\text { At least one of the solutions } \\
\text { presented is new and the } \\
\text { others are not based on } \\
\text { assumptions similar to those } \\
\text { presented or are still less } \\
\text { mentioned. }\end{array}$ & 3 \\
\hline & & $\begin{array}{l}\text { The solutions presented that } \\
\text { serve to solve the problem } \\
\text { are new and much referred. }\end{array}$ & 2 \\
\hline & & $\begin{array}{l}\text { The solutions presented are } \\
\text { modifications } \\
\text { improvements to the ones } \\
\text { proposed in the text. }\end{array}$ & 1 \\
\hline & & $\begin{array}{l}\text { The solutions presented the } \\
\text { same of those that are } \\
\text { proposed in the text. }\end{array}$ & 0 \\
\hline
\end{tabular}

The test total score ranges from 0 to 25 points. The interjudge reliability (Cohen kappa coefficient) ranged between .76 and .93. The results overall showed sufficient to high interrater reliabilities both at the item and the total score level [44].

\section{PROCEDURE}

To determine how cooperative learning effectively improved high students' critical-thinking skills, a 13-weeks period of experimental instruction (in a total of 13 lessons, lasting 120 minutes each) focusing on learning critical thinking took place in the experimental group. At the beginning of the semester 1) The teacher organized heterogeneous groups of four or five students; 2) He assigned roles to the different members of the group. The roles were rotating and were adjusted to the activities goals; 3) In the 13 lessons, the students in cooperative groups 3.a.) analyzed pedagogical scenarios, which entailed problem solving and 3.b.) read and analyzed papers on teaching-learning methods in which they had to develop the respective concept maps; 4) Works were exchanged between groups in order to give and receive feedback (peer feedback); 5) The teacher gave feedback to the work of each group after peer feedback; 6) Students improved the work carried out, incorporating feedback from colleagues (peer feedback) and teacher; 7) A final oral presentation was carried out by each group to the whole class; 8) A reflection on the functioning of the group (group process), strengths, weaknesses, and improvement strategies was made.

For the control group, the lessons were explained using a more traditional lecture-based approach in which the preponderant role was assigned to the teacher. Both, the experimental group and the control group took the pretest in the first week and completed the posttest (same test as the pretest) in week 13 .

\section{A. Ethical Considerations}

This project followed the ethical requirements of the EFPA - European Federation of Psychologists 'Associations, as well as of the OPP - Portuguese Psychologists' Order. All ethical principles have been respected, ensuring that all participants were familiarized and accepted the principles of informed consent, voluntary participation and the confidentiality of their responses.

\section{RESULTS AND DISCUSSION}

The data analysis were carried-out using SPSS - Statistical Package for Social Sciences (version 22.0). In all analyzes, the level of statistical significance considered was $5 \%$.

\section{A. Differential analysis of critical thinking between control and experimental groups in pre-test}

A paired-samples t-test was conducted to evaluate if there were significant differences between control and experimental groups regarding critical thinking. Results (Table 1) show that there were significant differences $t(39)=-2.505, p<.017]$ between the control group ( $M=13.68 ; S D=2.950)$ which had higher score results and the experimental group $(\mathrm{M}=11.37$; $\mathrm{SD}=2.950)$. The eta squared statistic (.025) indicated a small effect size.

TABLE 2. DifFERENTIAL ANALYSIS OF CRITICAL THINKING BETWEEN CONTROL AND EXPERIMENTAL GROUPS IN PRETEST

\begin{tabular}{|c|c|c|c|c|c|}
\hline Groups & $\mathbf{N}$ & Mean & SD & $\boldsymbol{t}$ & $\boldsymbol{p}$ \\
\hline Experimental & 19 & 11.37 & 2.948 & -2.505 & .017 \\
\hline Control & 22 & 13.68 & 2.950 & & \\
\hline
\end{tabular}




\section{B. Differential analysis of critical thinking between control and experimental groups in posttest}

A paired-samples t-test (Table 2) was conducted to evaluate the impact of the intervention on students' scores on the Critical Thinking Test (CTT). There was a statistically significant increase in scores from pre-test $(\mathrm{M}=11.37, \mathrm{SD}=$ 2.95 ) to post-test $[\mathrm{M}=16.53, \mathrm{SD}=3.27, \mathrm{t}(18)=-6.54, \mathrm{p}<.001]$ in the experimental group. The results indicated a large effect size $(\mathrm{d}=1.66)$.

TABle 3. Comparison Of Score Means, Standard Deviations, Mean DifFERENCES, EFFECT SIZE From THE CRITICAL THINKING PRE To POSTTEST BETWEEN EXPERIMENTAL AND CONTROL GROUPS

\begin{tabular}{|c|c|c|c|c|c|c|}
\hline Groups & $\begin{array}{c}\text { Critical } \\
\text { Thinking } \\
\text { Test }\end{array}$ & $\mathbf{N}$ & Mean & SD & $\begin{array}{c}\text { Mean } \\
\text { differences }\end{array}$ & $\begin{array}{c}\text { Effect } \\
\text { size } \\
\text { (Cohen } \\
\text { d) }\end{array}$ \\
\hline \multirow[b]{2}{*}{ Experimental } & Pre-test & \multirow[b]{2}{*}{19} & 11.37 & 2.95 & \multirow{2}{*}{$\begin{array}{c}\mathrm{t}(18)=- \\
6.54, \mathrm{p}< \\
.001\end{array}$} & \multirow[b]{2}{*}{$d=1.66$} \\
\hline & Post-test & & 16.53 & 3.27 & & \\
\hline \multirow[b]{2}{*}{ Control } & Pre-test & \multirow[b]{2}{*}{22} & 13.68 & 2.95 & \multirow{2}{*}{$\begin{array}{c}\mathrm{t}(21)= \\
1.86, \mathrm{p}= \\
0.76\end{array}$} & \multirow[b]{2}{*}{$\mathrm{d}=-0.5$} \\
\hline & Post-test & & 12.05 & 3.54 & & \\
\hline
\end{tabular}

These results seem to indicate that the diverse educational activities carried out with the cooperative learning approach contributed for the development of students' critical thinking. These activities allowed students to be involved in dialogic interaction processes, either within or between cooperative groups, when students have to negotiate their point of view [45] [46] [47]. These results are in line with the studies by the references [48] [49] [50] and [51] who showed that students improve their critical thinking skills working in cooperative groups as compared when they work individually using more traditional methods. While it encourages active participation in the acquisition of knowledge and promotes interaction with others, cooperative learning favors the development of individual relevant reflection skills. When the students have the opportunity to interact with different perspectives and opinions about the work at stake, as it happens with cooperative learning, they analyze critically the ideas, comment, compare the work, give, and receive feedback that can be used to enhance their critical thinking skills [52].

According to the reference [53] in cooperative groups, students feel free to risk, challenge, and question. There is student-to-student interaction focused on information processing, where students consider the ideas, contributions, and arguments of peers; teachers don't "tell", rather, they help students critically analyze ideas; students are encouraged to become active learners rather than passive recipients of information; and students take responsibility for their own thinking and learning [54]. As the reference [52] state, adolescents are able to develop higher order thinking skills (formal operations) through internalizing the viewpoints of other people, which takes place during dialogues with others. As the reference [24] explains that the process of making sense of the world is profoundly influenced by ones' interactions and perceptions of one's environment, followed by the reference [55] who stresses the potential students have to raise themselves to a higher intellectual level of development through collaboration. Discussion helps develop critical thinking because students do the thinking and there is an opportunity for them to check their thinking against each other [56] [57].

TABLE 4. Means, Standard Deviations And MEAn DifFEREnCES In CRITICAL ThINKING SKILLS TEST FOR PRE-TEST AND POST-TEST For EXPERIMENTAL AND CONTROL GROUPS

\begin{tabular}{|c|c|c|c|c|c|c|}
\hline & & \multicolumn{5}{|c|}{ Experimental Group $(n=19)$} \\
\hline Question & CT skill & $\begin{array}{c}M \\
\text { pre- } \\
\text { test }\end{array}$ & $S D$ & $\begin{array}{c}M \\
\text { post- } \\
\text { test }\end{array}$ & $S D$ & $\begin{array}{c}M \\
\text { difference }\end{array}$ \\
\hline 1 & Interpretation & 1.26 & 1.04 & 1.74 & .73 & .48 \\
\hline $2 \mathrm{a}$ & Analysis & 2.11 & .31 & 2.16 & .5 & .05 \\
\hline $2 b$ & Analysis & 1.05 & .4 & 1.63 & .59 & .58 \\
\hline 3 & Explanation & 1.26 & .99 & 2.42 & .96 & 1.16 \\
\hline 4 & Evaluation & .68 & .47 & 1,42 & .69 & .74 \\
\hline 5 & Synthesis & 1.32 & 1.1 & 2.47 & .96 & 1.15 \\
\hline 6 & Fluency & 1.53 & .69 & 1.42 & .69 & -.11 \\
\hline 6 & Flexibility & .95 & .4 & 1.95 & .78 & 1 \\
\hline 6 & Originality & 1.16 & .76 & 1.95 & .8 & .79 \\
\hline \multirow[t]{2}{*}{ Score } & CTT & 11.37 & 2.95 & 16.53 & 3.27 & 5.16 \\
\hline & & \multicolumn{5}{|c|}{ Control group $(n=22)$} \\
\hline Question & CT skill & $\begin{array}{c}M \\
\text { pre- } \\
\text { test }\end{array}$ & $S D$ & $\begin{array}{c}M \\
\text { post- } \\
\text { test }\end{array}$ & $S D$ & $\begin{array}{c}M \\
\text { difference }\end{array}$ \\
\hline 1 & Interpretation & 1.09 & 1.06 & 1.36 & 1 & .27 \\
\hline $2 a$ & Analysis & 2.05 & .375 & 2.23 & .42 & .18 \\
\hline $2 b$ & Analysis & .86 & .71 & 1.05 & .89 & .19 \\
\hline 3 & Explanation & 1.59 & .66 & 1.81 & .95 & .22 \\
\hline 4 & Evaluation & 1.05 & .66 & .95 & .65 & -.1 \\
\hline 5 & Synthesis & 1.23 & 1.11 & 1.64 & 1.32 & .41 \\
\hline 6 & Fluency & 1.45 & .67 & .82 & .5 & -.63 \\
\hline 6 & Flexibility & 1.77 & .42 & .77 & .42 & -1 \\
\hline 6 & Originality & 2.27 & .55 & 1.55 & .91 & -.72 \\
\hline Score & CTT & 13.68 & 2.95 & 12.05 & 3.54 & -1.63 \\
\hline
\end{tabular}

Note: $M=$ Mean; $S D=$ Standard Deviation

Results of table 3 show that in the experimental group, $84 \%$ of the students raised their critical thinking score from pre-test to post-test (Average gain of 5.16 points); in the control group, only $36.3 \%$ of the students increased their scores from pre-test to post-test (decreased of -1.63 points). The critical thinking skills main gains in the experimental group were in the explanation, synthesis and flexibility (production/creation) skills.

The gains in these critical thinking skills are certainly due to the type of activities carried out during the semester. The resolution of pedagogical scenarios, the reading and analysis of scientific articles on pedagogical methods and the construction of conceptual maps involve essentially the mastery of analysis and synthesis skills. The fact that these activities were implemented in cooperative groups implied the need for the students to present their points of view and to explain them. They also had to be receptive to consider other points of view as valid, to argue and to counter-argument [58] [29] [59]. 


\section{CONCLUSIONS}

The aim of this study was to analyze if there were any statistically significant diferences between the critical thinking skills development of the college students involved in a cooperative learning approach, compared with those submitted to a more traditional lecture-based classroom teaching.

Using the Critical Thinking Test, in the pre-test phase, there was a statistically significant difference in the mean between the control group and the experimental group, the total score being higher in the control group. In the post-test phase, the mean of the experimental group increased significantly compared to the control group's one, reflecting an increase of the critical thinking skills from the students belonging to the experimental group.

On the other hand, the skills with more significant raise in the experimental group (explanation, synthesis and flexibility (production/creation skills) seem to have been improved due to the features of the classroom activities involved as well as the active student participation, meaningful interaction with material, and student-to-student verbal interaction. The practical implications of the results of this study are clear. Professors may be able to increase student critical thinking skills by including cooperative learning approaches. They will thus enhance an important part of students' education contributing for their effective integration into society and the workplace as "better" thinking future citizens.

In future work, it would be useful to investigate the impact of the cooperative learning approach throughout the academic course, comparing the gains in critical thinking between students who learn with cooperative approaches and others who do not. Another important research concern should tackle the effects of cooperative learning on the development of critical thinking dispositions versus a more traditional pedagogical approach.

\section{ACKNOWLEDGEMENT}

This work was supported by the 'Critical Thinking Across the European Higher Education Curricula - CRITHINKEDU' project, with the reference number 2016-1-PT01-KA203022808, funded by the European Commission/EACEA, through the ERASMUS+ Programme.

\section{REFERENCES}

[1] D. F. Halpern and S. G. Nummedal, "Closing thoughts about helping students improve how they think," Teaching of Psychology, vol. 22, $\mathrm{n}^{\circ}$ 1, pp. 82-83, 1995

[2] S. L. Penningroth, L. H. , Despain and M. J. Gray, "A course designed to improve psychological critical thinking", Teaching of Psychology, vol. 34, pp.153-157, 2007.

[3] E. T, Pascarella, J. S. Wang, T. L. Trolian and C. Blaich, "! How the instructional and learning environments of liberal arts colleges enhance cognitive development. Higher Education", vol.66, nº5, pp.569-583, 2013.

[4] P. Facione, Critical thinking: What is it and why it counts. Measured Reasons and the California Academic Press, 2010.

[5] A. Lewis and D. Smith, "Defining higher order thinking", Theory into Practice, vol.32, n³, pp.131-137, 1993.

[6] H. Astleitner,"Teaching critical thinking online”,Journal of Instructional Psychology, vol.29, nº 2 , pp.53-75, 2002.
[7] R. H. Ennis, "Critical thinking assessment", Theory into Practice, vol.32, no3, pp.179-186, 1993.

[8] D. F. Halpern and H. Riggio, Thinking Critically About Critical Thinking, 4th ed. Mahwah, NJ: Lawrence Erlbaum Associates, Inc. Publishers, 2003.

[9] J. E. McPeck,"Critical thinking and subject specificity: A reply to Ennis", Educational Researcher, vol.19, no 4, pp.10-12, 1990.

[10] S. Norris and R. Ennis, Evaluating critical thinking. Pacific Grove, CA: Critical Thinking Press and Software, 1989.

[11] R. Paul and L. Elder, The miniature guide to critical thinking concepts and tools. Dillon Beach, CA: Foundation for Critical Thinking Press, 2008.

[12] V. R. Ruggiero, The art of thinking: A guide to critical and creative thought, 10th ed., New York, NY: Longman, 2012.

[13] P. Facione, Critical thinking: A statement of expert consensus for purposes of educational assessment and instruction (The Delphi Report). Millbrae, CA: The California Academic Press, 1990

[14] R., Arum and J. Roksa, Academically adrift: Limited learning on college campuses. Chicago, IL: University of Chicago Press, 2011.

[15] C. Blaich, Overview of findings from the first year of the Wabash National Study of Liberal Arts. Education. Wabash College, Center for Inquiry in the Liberal Arts, 2007.

[16] M. Browne and K. Keeley, Asking the right questions: A guide to critical thinking, Sixth Ed. Upper Saddle River, N.J.: Merrill/Prentice Hall, 2001

[17] M. Burbach, G. Matkin and S. Fritz, "Teaching critical thinking in an introductory leadhership course using active learning strategies: A confirmatory study", College Student Journal, vol.38, nº3, pp. $482-$ 494, 2004.

[18] D. W. Johnson and R. Johnson, Cooperation and competition: Theory and research. Edina, MN: interaction Book Company, 1989.

[19] M., Laal and S.M. Ghodsi," Benefits of collaborative learning", Journal of Procedia-Social and Behavioral Sciences, vol.31, pp. 486-490, 2012.

[20] T. Panitz, Benefits of Cooperative Learning in Relation to Student Motivation. In M.,Theall Ed., Motivationfrom within: Approaches for encouraging faculty and students to excel, New directions for teaching and learning. San Francisco, CA, USA: JoseyBass publishing, 1999.

[21] E. F. Barkley, K. P. Cross and C. H. Major, Collaborative Learning Techniques: A Handbook for College Faculty. Hoboken, NJ: John Wiley \& Sons, 2014.

[22] D.W. Johnson, R. Johnson and E. Holubec, Cooperation in the classroom, 7th ed. Edina, MN: Interaction Book Co, 1998.

[23] J. Piaget, The psychology of intelligence. New York: Harcourt, 1950.

[24] L. Vygotsky, Mind in society: The development of higher psychological processes. Cambridge, MA: Harvard University Press, 1978.

[25] D. W. Johnson and R. T. Johnson," Social interdependence theory and university instruction - theory into practice", Swiss Journal of Psychology, vol.61, n³, pp.119-129, 2002.

[26] N. Davidson and T. Worsham, Enhancing thinking through cooperative learning. New York, NY: Teachers College Press, 1992.

[27] R. E. Slavin, "Research on cooperative learning and achievement: What we know, what we need to know", Contemporary Educational Psychology, vol.21, pp.43-69, 1996.

[28] A. A. Gokhale, "Collaborative learning enhances critical thinking," Journal of Technology Education, vol. 7, pp. 22-30, 1995.

[29] A. Tiwari, P. Lai, M. So, and K. Yuen, "A comparison of the effects of problem-based learning and lecturing on the development of students' critical thinking," Medical Education, vol. 40 nº 6, pp. 547-554, 2006.

[30] L. Skon, D. W. Johnson, and R. T. Johnson, "Cooperative peer interaction versus individual competition and individualistic efforts: Effects on the acquisition of cognitive reasoning strategies," Journal of Educational Psychology, vol. 73, pp. 83-92, 1981.

[31] D. W. Johnson, R. T, Johnson., and K. A. Smith, Active learning: Cooperation in the college classroom. Edina, MN: Interaction, 1991

[32] E. F. Barkley, K. P. Cross, and C. H. Major, Collaborative learning techniques: A handbook for college faculty. San Francisco, CA: JosseyBass, 2014 
[33] E. Pascarella and P. Terenzini, How College Affects Students: A Third Decade of Research. San Francisco, CA: Jossey-Bass, 2005.

[34] H. Silva, J. Lopes, C. Dominguez, E. Morais, and M. Nascimento, "Fostering critical thinking through peer review between cooperative learning groups," Revista Lusófona de Educação, vol. 32, n 32, pp. 3145, 2016.

[35] V. Tinto, "Classrooms as communities: Exploring the educational character of student persistence," The Journal of Higher Education, vol. 68, n 6 , pp. 599-623, 1997.

[36] B. Goodman, "The one dimensional state of nursing education," Nurse Education Today, vol. 31, no 8, pp. 725-726, 2011.

[37] C. N. Loes, The impact of college residence and diversity experiences on the development of critical thinking in first-year college students (Doctoral dissertation). ProQuest Dissertations and Theses database, 2009

[38] C. Notar and S. Padgett, "Is thinking outside the box 21st century code for imagination, innovation, creativity, critical thinking, intuition,"? College Student Journal, Vol. 44, No. 2, pp. 294-303, 2010.

[39] Association of American Colleges and Universities, The LEAP vision for learning: Outcomes, practices, impact, and employers' views, 2011.

[40] J. Koenig, J. Herman, G. Duncan, D. Knapp, P. Kyllnonen, P. Sackett, and Iverson, K. Assessing 21st century skills: Summary of a workshop. Washington, DC: National Academies Press, 2011.

[41] J. R. Fraenkel, and N. E. Wallen, How to design and evaluate research in education. Fifth ed. New York: McGraw-Hill, 2003.

[42] Authors, Critical Thinking Test, unpublished.

[43] L. W. Anderson and D. R. Krathwohl, (Eds.), A taxonomy for learning, teaching, and assessing: A revision of Bloom's Taxonomy of Educational Objectives. New York, NY: Longman, 2001.

[44] J. Cohen, "A coefficient of agreement for nominal scales," Educational Psychology Measurement," vol. 20, nº 1, pp. 37-46, 1960.

[45] D. Klimoviene, J. Urboniene, and R. Barzdziukiene, "Developing critical thinking through cooperative learning," Studies About Languages, vol. 9, pp. 77-84, 2006.

[46] J. Fransen, A. Weinberger, and P. A. Kirschner, "Team effectiveness and team development in CSCL," Educational Psychologist, vol. 48, $\mathrm{n}^{\circ}$ 1, pp. 9-24, 2013.

[47] F. H. Van Eemeren, and R. Grootendorst, R. A., systematic theory of argumentation: The pragmadialectical approach (Vol. 14). Cambridge: Cambridge University Press, 2004.

[48] P. C. Abrami and B. Chambers, "Research on co-operative learning and achievement: comments on Slavin,", Contemporary Educational Psychology, vol. 21, n 1, pp. 70-79, 1996.

[49] R. Gillies, "The effects of cooperative learning on junior high school students during small group learning," Learning and Instruction, vol. 14, pp. 197-213, 2004.

[50] L. Lafont, M. Proeres, and C. Vallet, "Cooperative group learning in a team game: role of verbal exchanges among peers. Social Psychology of Education, vol. 10, pp. 93-113, 2007.

[51] P. Vijayaratnam, Cooperative learning as a means to developing students' critical and creative thinking skills Proceedings of the 2nd International Conference of Teaching and Learning (ICTL 2009) INTI University College, Malaysia, 2009.

[52] D. Barnes and F. Todd, Communication and Learning in Small Groups. London: Routledge and Kegan Paul, 1977.

[53] B. K. Beyer, Practical strategies for the teaching of thinking. Boston: Allyn \& Bacon, 1987.

[54] D.F. Halpern, Critical thinking across the curriculum: methods and strategies to promote critical thinking in every classroon1. In M. Heinian \& J. Slomianko (Eds.). Thinking Skills: Concepts and Techniques, Washington, D.C.: National Education Association, 1987, pp.69-76.

[55] C. Garside, "Look Who's Talking: A Comparison of Lecture and Group Discussion Teaching Strategies in Developing Critical Thinking Skills," Communication Education, vol. 45, nº 3, pp. 212-227, 199).

[56] F. Smith, To think. New York, NY: Teachers College Press, 1990.

[57] P.J. Vermette, "Cooperative grouping in the classroom," The Social Studies, vol. $79, \mathrm{n}^{\circ}$ 6, pp. 271-273, 1988.
[58] C. Loes and E. Pascarella, "Collaborative Learning and Critical Thinking: Testing the Link," Journal of Higher Education, vol. 88, pp. 726-753, 2017.

[59] C. Tseng, "Teaching "Cross-Cultural Communication" through Content Based Instruction: Curriculum Design and Learning Outcome from EFL Learners' Perspectives." English Language Teaching, vol. 10, $\mathrm{n}^{\circ}$ 4, pp. 22-34, 2017. 